\title{
The Sustainability of Dam Construction through Environmental Management
}

\author{
Adeniji Olawale Aladelokun (Phd) \\ Department of Geography, College of Education, Ikere-Ekiti, Ekiti State. Nigeria.
}

\begin{abstract}
This paper examines dam construction in relation to positive and negative socio-economic impacts. It is affirmed that Environmental Impact Auditing (EIA) holds the key to lowering negative impacts. It is a well known fact that dam construction impacts are multi-disciplinary as climatology, geology, biodiversity, etc are affected, with each having feedback effects. Environmental managers and planners must therefore seek to combat negative impacts of dam construction with the use of cognate Environmental Management Plans $(E M P S)$.
\end{abstract}

\section{Introduction}

Water management projects have a long history as their desirability was recognized even in early civilization especially in regions of insufficient rainfall (Adams, 1975). As observed by Garbrecht (1983) such great civilizations as those in the valley of the Nile, the Tigris and Euphrates, the Indus and Hong-ho were able to develop on the basic of complex and advanced water management systems. Going by the report of Odihi (1991), it is possible by such means as "Advanced Water Management System" for many to ensure adequate supply of water in time and in space which will result in meaningful improvement of the quality of life for communities hitherto trapped in poverty and misery brought about by lack of potable water.

All living things on the earth depend on water and the earth is the only confirmed planet where water is present in liquid form, falling as precipitation and flowing through the landscape (Bruce, 1992). As there is a long history of water management projects, so also, are there numerous reports and publications of dams and their impact on the environment and life in general. This paper focuses attention on the various aspects of dams at global, regional and local levels. The discussion includes the functional aspects or justification for dam construction, dam impacts on socio-economic activities as well as history of water development projects. Effort is equally made to highlight the importance of the Environmental Impact Auditing (EIA).

\section{An Overview on Dam Construction}

A Dam according to Chorley (1969) is a barrier constructed across a stream or river to impound water and raise its level. Mcgraw-Hill Encyclopedia of Science and Technology (1960) defines a dam as a structure that bars or detains the flow of water in an open channel or watercourse. In the same and manner, Encyclopedia International (1980) describes dam as an artificial barrier across an open channel of water to create a reservoir or raise water level. It is a barrier built across a river to create a lake (Hornby, 2000). However, Iwena, (2000) sees a dam as an extensive area occupied by water trapped on a river course. From the foregoing, therefore, a dam can generally be defined as barrier built across a water course to hold back or control the flow of water for storage, diversion or detention.

The construction of dams have been going on from early man's period of civilization as evidence are available in the region of Bacelonia around Euphrates and Tigris in present-day Iraq. The construction of barrier across streams channels for the purpose of impounding water goes back to about 5,000 years from now (Sharma and Sharma, 1990).

In most cases, the ideas for which these dams have been constructed have to a great extent been accomplished at both individual and societal levels. According to Ayoade (1988), large projects in historical development have been undertaken in Africa not for power but as multipurpose schemes. The first modern dam scheme was the Gezira project developed from 1913 to 1950. It consists of a system of irrigation canals and sehar dam, which direct water from the Blue Nile into the main canal.

WCED (1987) observed that in the Republic of Cameroon, in addition to Lagolo Dam, other dams including Song-Loulon and Edea Dams on the Sanaga River are respectively the third and fourth largest dams in West Africa after Kanji Dam on the River Niger in Nigeria, and the Akosombo Dam on the Volta River in Ghana.

NEST (1991) documented that, dams have been built in Nigeria since about 1918 notably for domestic water supply. Hamadou (1997) reported that in Nigeria, right from 1920, hydro-electric power was generated on the Jos Plateau. In 1964, the first major hydro-electric power project in Nigeria started with the building of a dam across the Niger River at Kainji. In 1967, the first phase of the project was completed. At present, the 
Federal Government of Nigeria has spent billions of Naira to construct many dams for potable water supply and hydro-electric power generation. The Bakolori Dam built in mid 70s on River Sokoto in the North Western part of the country floods 30,000 hectares of arable land with irrigation water. In a village Bugauda, South of Kano, the Tiga Dam in Kano State was built. Also, the Shiroro Dam and Kanji Dam in Niger State were constructed in 1993 and 1964 respectively with the purpose to serve industries with electricity.

The number of dams and irrigation projects according to NEST (1991) has been increasing rapidly and feasibility studies are being carried out for most of larger rivers in Nigeria. Hamadou (1997), however, observed that besides the Hydro-Electric Power (H.E.P) these dams serve in the development of water supply, irrigation agriculture, control of floods etc.

\section{Types of Dams}

Iwena (2000) classifies dam on the basis of structural form and material used. Dams are also often classified according to their mode of impoundment and the use for which they are built. To this end, dams are classified into four major types viz: gravity dams, arch dams, buttress dam and earth-filled dams. The Gravity dams are solid concrete structures with triangular cross sections. The dam is thick at its base and thinner towards its tops. When view from the top, it is either straight or only curved and the upper stream is nearly vertical. It is described by Encyclopedia International (1980) and Babalola (2003) as roughly triangular dams in cross section. The broad based gravity dam holds water by the brute force of its weight. An example of this type is found on Columbia River in Washington.

Arch Dams are those that employ the same structural principles as the arch bridge. Arch dam is a type whereby the upper stream curve of the slender dam directs water pressure through the abetment to the retaining canyon walls. It is normally built in the form of up ended arch with bases on the walls of canyon. Arch dams are thinner and therefore require less material than any other type of dam. Arch dams are good for sites that are narrow and have strong abutments. They are usually made of concrete and more often in the shape of a $\mathrm{V}$ than $\mathrm{U}$ - shape. The gorge is often in the shape of a V, less often it is a U-shape. They use much less of concrete than gravity dams. The best design is a double-curved arch. Arch dams are generally classified as thin, medium and thick, depending on the ratio of the width of the base (b) to the height (h). Examples of this type of dam are the Kariba Dam in Rhodesia; the Glen Canyon Dam on the Colorado River in Arizona, which is $216 \mathrm{~m}$ high, and $475 \mathrm{~m}$ long; the Vallon de Baume in France which is $12 \mathrm{~m}$ high and $18 \mathrm{~m}$ long and curved with a radius of about $14 \mathrm{~m}$; and the Monte Novo dam in Portugal which is about $5.7 \mathrm{~m}$ high and $52 \mathrm{~m}$ long, including the wing walls at both ends.

Buttress Dams are watertight upstream face and a series of buttresses that support the face and the water pressure and the weight of the structure to the foundation. (Encyclopedia International,1980). An example is the Pidima Dam built in 1953 in Greece.

Encyclopedia International (1980) describes Earth-filled Dam as those that utilize natural materials with minimum of processing and may be built with primitive equipment under addition where any other construction materials would be impracticable. They are the earliest known dams and seem to be the easiest to construct. However, numerous failures of many earth-filled dams that are poorly designed make it an apparent threat. Earth-filled Dams require much more engineering skill in their conception and construction that any other types of Dam. The highest earth-filled embankment dam in the world is the Oroville Dam in California. Embankment Dam is the type of dam with earth materials, rock and dirt. It is the oldest form of Dam. It generally costs less than those concrete dams. It is interesting to note that Ero Dam in Mobal Local Government Area of Ekiti State falls into this category.

\section{Environmental Impact Auditing for Sustainable Management of Dams}

Environmental Impact Auditing is simply the assessment of the potential impacts of proposed projects on the environment. It is an environmental management tool used to determine the impacts of a project or operation on the environment (SPDC, 1994). EIA is a process or study in which the potential physical, biological, economic and social impacts of a proposed infra-structural development on the immediate and more distant environment are identified, analyzed and predicted (Canter, 1977 and Odiette, 1993)

Environmental Impact Auditing (EIA) is a process based on current scientific knowledge used to predict the environmental consequences of a proposed action, project or programme and to provide decision makers with systematic information presented in such a way that the impacts as well as mitigating needs can be presented in spatio-temporal perspective (Stromgquist and Tathamn, 1992).

The history of EIAs in developing countries dates back to the late 1970s when the first EIAs mostly followed the criteria and procedures practised in the donor country (Kakonge and Imevbore, 1993) which might have hampered the development of EIA in the individual countries by not taking into account the 'local' environment and associated environmental problems.

Historical legacy of sustainable development dates back to 1972 at the Stockholm's environmental debate and in 1992 at the Environment and development crusade in Rio de Janiero and also in 2002 at Durban 
sustainable development summit. The Durban Summit added poverty alleviation to the theme of the discourse. This was however based on the premise of the Stockholm Summit which states that the resources of the world are limited and its ecosystem fragile and vulnerable to change.

Agenda 21, the central document of the United Nations Conference on Environment and Development (UNCED) in Rio de Janerio in 1992, defined sustainable development as a 'global partnership for economically viable socially equitable, ecologically sound development not only for today but also for the future: Among the major point of discussion of the Rio conference are gradual elimination of ozone depleting substances, Green House gas reduction, biodiversity conservation and protection of international waters.

Sustainable development requires that environmental resources should be used functionally and judiciously. It requires adequate planning of developmental activities so as to enhance long term resources use. From the foregoing, a clear understanding of the concept shows that sustainability does not mean that resources should not be used at all. In this regard, sustainability borrow support from the concept of preservation which implies that resources be exploited in such a way that is renewable or regeneration is assured.

Development itself was noted by Brechery (1992) to depend on what social goals are being advocated by the development agency, Government, analyst or adviser. That is, a list of attributes which society seeks to achieve or maximize. Drawing from this, therefore, development can be conceived as the utilization of natural resources. Therefore, the sustainable use of resources means the ability to seize opportunities in managing environmental problems.

Houghton (1999) noted rightly that sustainable development means the long term survival of the planet earth and its process of dynamic evolution, including the wide range of species which currently lives on it, not least the human kind. For human kind, it specifically requires achieving a position which allows for living in harmony with nature, that both life and resources are managed efficiently for optimum support of man and other life- forms. From the stand point of Houghton (1999), it can be asserted or inferred that vandalisation and destruction of cherished biodiversity are environmentally hazardous and deleterious to human habitation as well as to the environment.

Further, on development and sustainability the World Commission on Environment and Development (1987) defines sustainable development as "a process of change in which the exploitation of resources, the direction of investments, the orientation of technological development, the institutional change are all in harmony and enhance both current and future potentials to meet human needs and aspiration.

From the foregoing, it is obvious that UNCED (1992) prescribes antidote for wasting resources as a process for integrated activities and actions aimed at re-cycling value- added resources through use. That is, such an approach does not only meet the need of the present but will not compromise the needs of future generations. Sustainability means that the present generation must not rub the coming generations. Rather, we must leave an ecological footprint of judicious use of environmental resources in such a way that they become 'renewable'. This could otherwise be regarded as socio- cultural and economic sustainability. From the environmental point of view, sustainable development means the use of environmental resources in such a way that the action is not hazardous or deleterious to the environment and the components therein.

Whatever is the nature and type of project in supra-urban space, certain changes are imminent in the environment as well as in the socio-economic life of the people as a result of these interventions. Hence, the necessity of the Socio-economic and EIA to be carried out in order to identify, quantify and evaluate the nature and magnitude of impacts of these changes in the biological, bi-geophysical, economic and political environments in which such projects are located and more importantly, in which humanity must operates (Olokesusi, 1994).

Studies on environmental impact of dam construction have demonstrated that dams and reservoirs have significant impacts on the environment in their drainage basin while providing solution to water and power deficiency most especially in drought prone areas of Nigeria (Olofin, 1980). This implies that such impacts can either have adverse or beneficial effects on the quality of the environment or on the sum total of the resources comprised within it. Aladelokun (2010) working on Ero Dam in Ekiti State asserted that impacts may be primary or secondary, short-term or long-term, irreversible or quasi-permanent. The primary impacts are caused generally by project "input". These include change in land use, land ownerships, vegetative species composition, noise of equipment, dust during land clearing, and more importantly, a change in electricity output. The secondary impacts on the other hand are usually caused by project "output". They are indirect or induced changes and typically these include the associated investments and changed patterns of social and economic activities that are stimulated or induced by the project.

Short-term impacts are those that have immediate impacts of short-duration such as noise, dust, erosion and flood, application of herbicides to remove undesirable species, while the long lasting or cumulative effects of these agents may permanently damage other vegetative growth or result in disruption of ecological balance. The importance of giving special consideration to both short-term and long-term effects is to enable us to assess the cumulative impacts of the project, which either significantly reduce or enhance the state of the environment for future generations. 
The "irreversible impacts apply primarily to non-renewable resources. Endangered species, fossil fuels, minerals or wildlife situation through sub-soil exposure often involve irreversible effects.

Irretrievable effects on the other hands are the adverse effects on some value that will be lost and cannot be restored. These among others, include an endangered or threatened animal that may become extinct or destruction of unique habitants for wildlife, increase freshwater flow into water bodies changing the balance in coastal/marine environment, change of flow of water in river due to impoundment and irrigation scheme downstream, change in labour and capital investment.

\section{Conclusion}

The rate of development has increased since the world entered $21^{\text {st }}$ century. Closely associated with the trend of development are socio- economic and environmental problems like flooding, bio-diversity loss, pollutions etc. There are isolated and non-integrated approaches for combating these problems. Each problem requires its own strategy of reduction or prevention. However, for environmental sustainability to be achieved, the problems must be combated at the stage when the impact is least felt. Then an integrated holistic approach must be adopted.

The prevention of adverse consequences of Dam construction requires the application of different techniques. Specifically, this could be achieved through environmental design to ensure sustainability. A meaningful strategy therefore should not end in the planning studio or on the drawing board. Sustainable development requires adequate implementation monitoring. It requires advocacy planning as well as citizen participation. Naresh and Richard (1996) advocate an integrated strategy to meet the needs of people, the economy and ecosystem through proper decision making.

There seems to be greater consensus among those advocating sustainable development that greater emphasis must be place on full and true valuation of the natural, built and cultural environment. With the foregoing as a background, one can rightly say that the issue of sustainability is very important in combating negative consequences of Dam construction through environmental design. For it to be achieved, local communities should have inputs in potential Dam construction consequences and possible reduction measures.

The campaign for the prevention of negative consequences of Dam through environmental design is an attempt to reduce and eliminate environmental and social-economic destruction and to correct the damages of the past. It is sustainable and futuristic in its perspective. It is a kind of development that offers a vision of the need of the present generation without undermining the integrity of the environment, and without equally jeopardizing the interest of the future generation (Sousan, 1992).

The struggle for environmental sustainability entails the availability of effective and environmental friendly technologies. Sustainability on this note requires the utilization of economical resources without changing it, secure adequate resources for sustainable human consumption, and support fairness, cooperating and well-being in the effort towards human development and social health. Which satisfies the basic needs of humanity, ensuring survival, healthy human development, and the expression and free pursuit of the full range of human aspiration ( Naresh and Richard, 1996).

In other development, NERC (2004) posited that environmental cost accounting will help us in achieving the goals of the much needed environmental sustainability. It is stressed that EIA help us to avoid or restore the effect we have on the environment. It is equally noted that even though, science and technology is more needed for the development of sustainable development, the growth of science and technology is equally posing some environmental 'footprint'. The publication referred to EIA as a management tool that can help us to improve our performance and plan for dealing with risk and liabilities.

According to the World Bank (2003), the core challenge for sustainable development is to ensure a better quality of life for all the people while meeting everyone's aspiration for social well being. To achieve this, it is necessary to sustain critical ecosystem services and strengthen the social fabric that underpins development.

This paper helps to establish the fact that tangible improvement in people's living condition in the thematic spheres mention above will no doubt reduce the rate and extent of negative Dam consequences and tendencies. The challenges ahead therefore have triggered the preparation of the environment strategy that will better align the management of environment and natural resources with sustainable development.

\section{References}

[1] Adams, W. M. (1975) The Downstream Impacts of Dams Construction, Nigeria Transactions. Institute of British Geographers. New Series. No 10 Pgs. 290-307

[2] Aladelokun, A.O. (2010) Some Socioeconomic and Environmental Impact of Ero Dam in Moda Local Government Area of Ekiti State. A Ph.D. Thesis, Department of Geography and Environmental Management. University of Abuja, Abuja.

[3] Babalola, A.I. (2003) Economic Impacts of Dam Construction in Ekiti State. N.C.E. Long Essay, College of College of Education, Ikere Ekiti.

[4] Brecchery, M.J. (1992) Towards sustainable Urban Development in Marinas, A.M. and S.R. Bowlty (eds). Environmental Issues in the 1990s. Chichester, John Wiley.

[5] Bruce, J.O. (1992), Meteorology and Hydrology for Sustainable Development. World Meteorological Organization. 
[6] Center, L.W. (1977) Environmental Impacts Assessment, New york Mc Graw Hill.

[7] Charley, R.J. (1969) Introduction to geographical hydrology U.S.A. Harper and Row publishers.

[8] Encyclopedia International (1980) Lexicon publication. Vol. 5. pgs 425 - 427

[9] Garbrecht, C.J. (1983) An Environmental Evaluation System for Water Resource Planning. Water Resource Research, 9 , 523 - 532.

[10] Hornby, A.S. (2000) Oxford Advanced Learner's Dictionary of Current English. Edited by sally Wehmeir and Michael Ashby. New york, Oxford University Pres

[11] Houghton, G. (1999) Environmental Justice and the Sustainable City. In David, S. (ed) Sustainable Cities. Condoms Earth scan, 6279.

[12] Iwena, O.A. (2000) An Essential Geography For Secondary Schools. Ikeja, Tonad Publishers Nig. Ltd.

[13] Kakonge, J.O. and A.M. Imevbore (1993) Constrains of Implementing Environmental Impact Assessment in Africa. Environ Impact Assessment 13. $299-308$

[14] Mcgraw- Hill Encyclopedia of Science and Technology (1960) Library of Congress. Vol. 4. Pgs 8-10.

[15] Naresh, C.S. and S. Richard (1996) From Legacy to Vision: Sustainability, Poverty and Policy Adjustment. Winningpeg, Canada. International Institute for Sustainable Development (IISD).

[16] NEST (1991) Nigeria: A Threatened Environment. A National Profile, Ibadan. Macmillan. 32.

[17] Odiette, W.O. (1993) Environmental Impact Assessment for Sustainable Development. Environmental News. Oct - Dec.

[18] Odihi, J.O. (1991) Downstream problems of Dammed Rivers in Nigeria. A Case Study of Water Resources Development. A paper presented at Nigeria Geography Association conference.

[19] Olofin, E.A. (1980) Some Effects of Tiga Dam on the Environment D

[20] Olokesusi, F. (1994) The Environmental Impact Assessment Process Initiating it and making it work for Nigeria. Proceeding of the NNPC Seminar on the Petroleum Industry and the Nigerian Environment. Lagos, Nigeria. NNPC

[21] SPDC (1994) Environment, Newsletter.

[22] Stromquist, L. and S. Tathamm (1992) A practical Approach to Environmental Impact Assessment in Developing Countries. In Stromquist, I (ed) Environmental Impact Assessment: Notes on Applied Research, UNGI report N0 82. Uppsala University, Uppsala, Suredem. Pgs $1-43$

[23] UNCED (1992) United Nations Conference on Environment and Development.

[24] W.C.E.D. (1982) Our Common Future: London Oxford University Press. 